OPEN ACCESS

Edited by: Simon Haberle, Australian National University, Australia

Reviewed by:

Thomas A. Minckley, University of Wyoming, USA

Chad Steven Lane,

University of North Carolina at Wilmington, USA

${ }^{*}$ Correspondence:

Patrick T. Moss

patrick.moss@uq.edu.au

Specialty section: This article was submitted to Paleoecology,

a section of the journal Frontiers in Ecology and Evolution

Received: 06 June 2016 Accepted: 15 August 2016

Published: 30 August 2016

Citation:

Moss PT, Gehrels WR and Callard SL (2016) European Impacts on Coastal

Eastern Tasmania: Insight from a High-Resolution Palynological Analysis of a Salt-Marsh Core.

Front. Ecol. Evol. 4:105. doi: 10.3389/fevo.2016.00105

\section{European Impacts on Coastal Eastern Tasmania: Insight from a High-Resolution Palynological Analysis of a Salt-Marsh Core}

\author{
Patrick T. Moss ${ }^{1 *}$, W. Roland Gehrels ${ }^{2}$ and S. Louise Callard ${ }^{3}$ \\ ${ }^{1}$ Climate Research Group, School of Geography, Planning and Environmental Management, The University of Queensland, \\ Brisbane, QLD, Australia, ${ }^{2}$ Environment Department, University of York, Heslington, UK, ${ }^{3}$ Department of Geography, Durham \\ University, Durham, UK
}

A high-resolution pollen and micro-charcoal $(>5 \mu \mathrm{m})$ record has been produced from a short sediment $(50 \mathrm{~cm})$ core recovered from a salt marsh in the Little Swanport Estuary, eastern Tasmania. This record suggests that there are four phases associated with the European settlement of the region. An initial phase from around 1830 to 1858 AD, which is similar to the previous Aboriginal period; a relatively low impact transitional phase from 1859 to 1898 AD; a rapid and marked deforestation period from 1899 to 1932 AD; and establishment of the contemporary landscape, with reforestation occurring, but with marked differences in species composition (i.e., greater representation of exotic taxa and altered understorey composition) from 1933 to 2006 AD. Key similarities are seen across Australia with the European settlement phase (i.e., addition of exotic taxa, deforestation and/or changes in vegetation composition, alterations in fire regimes and increased sedimentation rates), but high-resolution analysis suggests that these impacts may manifest in different ways depending on the local environmental setting and/or historical context of the settlement location. Furthermore, Amaranthaceae pollen representation appears to be impacted by changes in sea level. However, other factors such as human modifications, particularly grazing, and climate variability may play additional roles and further research is required to disentangle the relative effects of these factors.

\footnotetext{
Keywords: pollen, micro-charcoal, European settlement, exotic taxa, land clearance, vegetation composition, Amaranthaceae, sea level
}

\section{INTRODUCTION}

European settlement of Australia, as well as other New World landscapes, has profoundly altered human-environment relationships (Roberts et al., 2001). In a general sense these impacts are well understood for the Australian environment, with significant land clearance for agriculture, forestry and mining; rapid introduction of exotic species; extinction of native taxa; and the imposition of new fire regimes (Adamson and Fox, 1982; Hobbs and Hopkins, 1990; Benson, 1991; Kirkpatrick, 1999; Bickford and Gell, 2005; Moss et al., 2007; Bickford et al., 2008; Romanin et al., 2016). However, at the regional scale, there are relatively few attempts to examine European impacts using palaeoecological proxies, due to the relatively low-resolution of existing Holocene reconstructions (Kershaw et al., 1994) that often attempt to provide insight into Holocene environments and/or 
focus on Aboriginal human-environment relationships (e.g., Colhoun and Shimeld, 2012; Ulm, 2013; Fletcher et al., 2014, 2015; Rees et al., 2015; Mackenzie and Moss, in press for recent publications from Tasmania). Those records that do exist suggest that there is a great deal of regional variation in the timing and nature of ecosystem response to European settlement, with some alterations linked to obvious European impacts, such as land clearance (e.g., Moss et al., 2007), while other ecological alterations are linked to much more subtle changes in land management, particularly the imposition of new fire regimes (e.g., Fletcher et al., 2014).

An understanding of how European impacts manifest in the palaeoecological record can also improve interpretations of pre-European reconstructions, as this provides insight into how landscapes have responded to dramatic human induced alterations, such as significant land clearance, which may provide the opportunity to disentangle the relative effects of natural climatic alterations and anthropogenic factors. More subtle interactions can also be examined, particularly the imposition of new fire management regimes and the potential impacts that this may have (i.e., vegetation thickening), which has been documented in tropical regions of Australia through remote sensing and in the palaeoecological record (e.g., Russell-Smith et al., 2003; Moss et al., 2015). Furthermore, due to extensive ethnographic evidence, the palaeoecological record during the immediate and post-European settlement phase can be enhanced, and potential links to socioeconomic changes can also be examined in detail. This study will provide insight into the scale of European impacts for coastal eastern Tasmania through the high-resolution analysis of a 180-year record from a salt marsh located in the estuary of the Little Swanport River.

\section{STUDY SITE}

The salt marsh that forms the basis of this study is located in the estuary of the Little Swanport catchment $\left(42^{\circ} 20^{\prime} 31^{\prime \prime} \mathrm{S}\right.$, $147^{\circ} 55^{\prime} 55^{\prime \prime} \mathrm{E}$ ), eastern Tasmania (Figure 1). The Little Swanport River (around $60 \mathrm{~km}$ long) forms the main component of the catchment, which drains an area of 87,600 ha and discharges into Great Oyster Bay via the Little Swanport Estuary (LSCPIC, 2010). The catchment is situated in the generally drier region of eastern Tasmania, with mean annual rainfall around $800 \mathrm{~mm}$ in the western higher elevations of the catchment, then dropping to between 500 and $625 \mathrm{~mm}$ at the Little Swanport Estuary and with most precipitation occurring in winter and spring (June to November; Hedge and Kriwoken, 2000; LSCPIC, 2010). The geology of the catchment is dominated by Jurassic Dolerite on the higher elevations, with resultant soils being prone to sheet, rill and gully erosion under major disturbance. Triassic sandstones are found at the Little Swanport Estuary (including the study
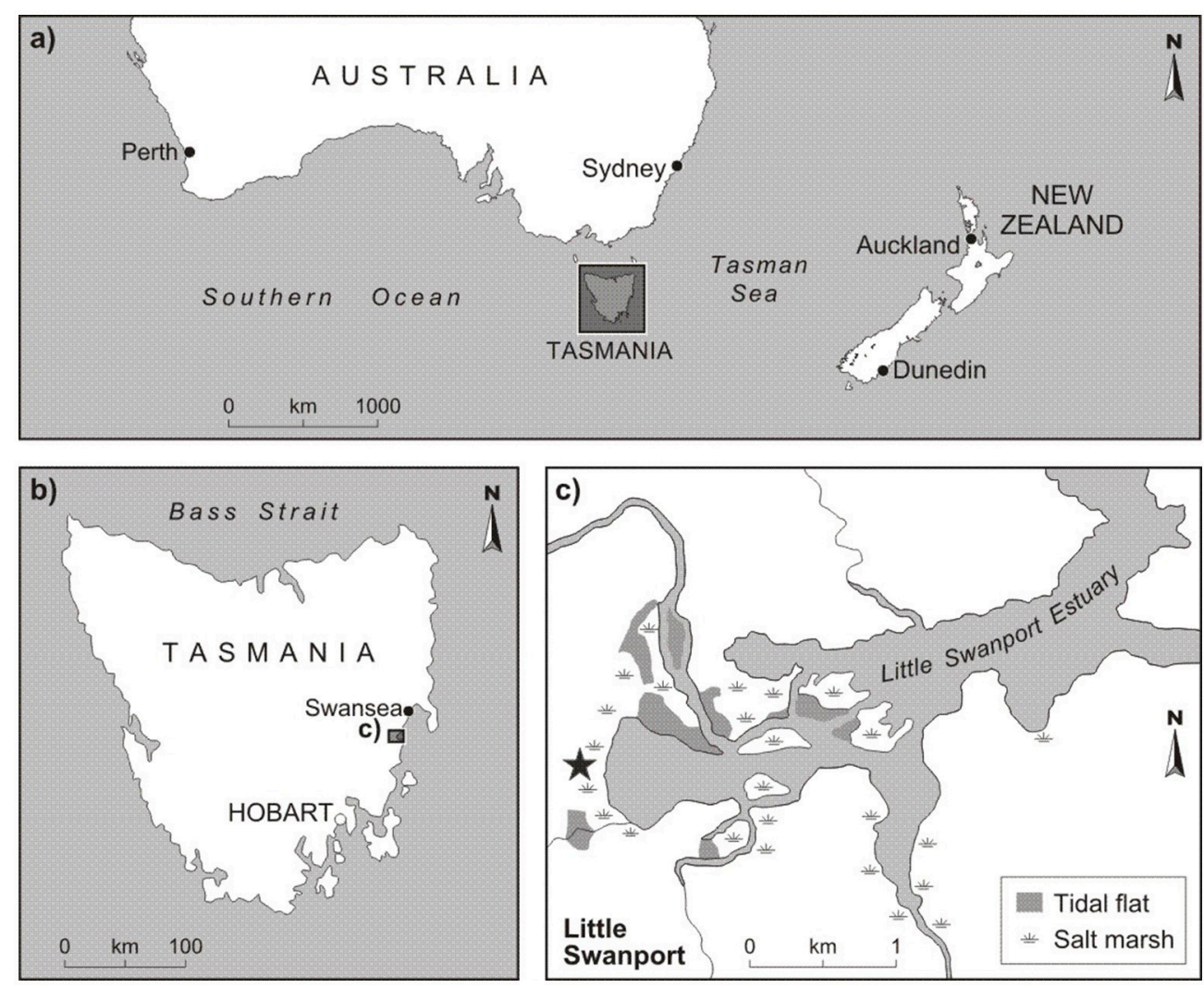

FIGURE 1 | Location of Tasmania (A), Little Swanport Estuary (B), and the core location (C), which is marked by the star. 
site) and form deep-grayish-brown silty or sandy clays that are prone to flooding and water logging in the wetter winter months (LSCPIC, 2010). The resultant climate and geology has produced a highly diverse native vegetation assemblage across the catchment, with small areas of rainforest in the deep, south facing slopes and wet sclerophyll forest in the fertile soil areas of the high elevation regions. However, the catchment is dominated by dry sclerophyll forests, consisting of a eucalypt species canopy and various understorey components from tussock grass to dense prickly shrubs. Heath and scrub form the riparian community of the Little Swanport River and associated streams, while the salt-marsh areas of the estuary (including the study area) contain extensive areas of shrub samphire (Sclerostegia arbuscular), as well as other salt-marsh species and associated plants (DPIW, 2006; LSCPIC, 2010).

A key characteristic of the Little Swanport site, and more broadly Tasmania, is the winter (June to August) dominated precipitation patterns that are linked to the mid-latitude westerly winds (Garreaud et al., 2009), which bring depressions and rainbearing troughs to the island (Pitman et al., 2004; BOM, 2005). There are two key drivers associated with modern precipitation variability for Tasmania, including the El Niño Southern Oscillation (ENSO) phenomenon and the Southern Annular Mode (SAM). ENSO is linked to changes in ocean temperature and pressure gradients through the Walker circulation across the Indo-Pacific region and observes two key states, El Niño and La Niña phases (Risbey et al., 2003). The El Niño (warm) phase is linked to warmer ocean temperatures and above average mean sea level barometric pressure over Indonesia and northern Australia, while the central Pacific experiences below average pressure, with the general consequence of decreased rainfall for Tasmania (Hill et al., 2009). In contrast, La Niña (cool) events observe the strengthening of the pressure gradient between the western (low) and eastern (high) Pacific, producing the potential for higher precipitation in Tasmania (Hill et al., 2009). SAM is an index of the seasonal to decadal shift in the position and intensity of the westerly winds. A positive SAM event is linked to a southward shift of the westerlies and a significant decline in precipitation in Tasmania, while the reverse is true for a negative SAM phase (Hendon et al., 2007; Hill et al., 2009). Fogt and Bromwich (2006) have identified that SAM is modulated by interactions with ENSO, amplifying alterations in precipitation linked to complimentary trends in each phenomenon, with this variability observed in dramatic differences in the discharge rates of the Little Swanport River (DPIW, 2006). Over the Holocene period, Fletcher et al. (2015) have demonstrated the influence of an increase in ENSO frequency and amplitude at a sub-millennial scale over the last 5000 years on fire activity (increased biomass burning) in South West Tasmania, which is also observed more broadly across the mid- to high-latitudes of the South Pacific region (McGlone et al., 1992; Shulmeister, 1999; Fletcher and Moreno, 2012).

European settlement of the Little Swanport catchment dates back to the 1820 and 1830s, with the nearby town of Swansea becoming established in 1821 by George Meredith (von Steiglitz, 1955) and with the establishment of the Lisdillon salt-works by James Radcliff at the northern side of the entrance to Little
Swanport Estuary around 1830 (von Steiglitz, 1955; Rogers, 1991; Parks and Wildlife Service Tasmania, 2016). Road links between Little Swanport (and Hobart) to the Swansea district were established in 1843 (von Steiglitz, 1955; Smith, 1969). Current and historical land-use within the catchment is primarily focused on agriculture, with $19 \%$ of the area being used for sheep and cattle grazing, and $8 \%$ utilized for plantation forestry. The catchment has a current permanent population of between 500 and 700 people (LSCPIC, 2010). Most of the agricultural activity occurs within the upper and lower catchments, with plantation forestry situated in the upper catchment and a number of smaller rural landholdings, as well a substantial oyster farm located in the estuary region. Due to the step aspect characteristics of the middle catchment there is still a large amount of natural forest present, with a significant proportion used for forestry production or in conservation reserves (LSCPIC, 2010). Evidence of Aboriginal occupation within eastern Tasmania dates to around 7000 years ago, with extensive shell middens located across the coast, including the Little Swanport Estuary (Lourandos, 1970; Brown, 1991).

\section{METHODS}

A $50-\mathrm{cm}$ sediment core was collected in 2006 from the central part of the Little Swanport salt marsh using a Russian D-section corer and was sub-sampled for palynological analysis (at 1$\mathrm{cm}$ increments) at the School of Geography, Planning and Environmental Management, The University of Queensland. The site was originally investigated to determine changes in sea level for the last few 100 years and discussion of this analysis can be found in Gehrels et al. (2012). A key component of this study was to establish a reliable chronology for the development of a foraminifera derived sea-level reconstruction and this chronology has been applied to the pollen and microcharcoal results discussed in this paper (Table 1). Gehrels et al. (2012) provide age control for the core, which is based on radiometric dating techniques, including Accelerator Mass Spectrometry (AMS) ${ }^{14} \mathrm{C}$ (15 dates), ${ }^{137} \mathrm{Cs}$ (1 date), and ${ }^{210} \mathrm{~Pb}$ (10 dates), as well as chronostratigraphic markers, including metal concentrations (i.e., lead, copper and zinc reflecting the occurrence of mining/refining within Tasmania and more broadly across South East Australia), Pb isotopic markers and presence of exotic pollen (Figure 2). Two additional AMS ${ }^{14} \mathrm{C}$ dates were obtained from shells present in the buried intertidal muds beneath the salt-marsh sediments and which were retrieved using a gouge auger. These ages are $4414 \pm 37^{14} \mathrm{C}$ years BP (2286-2940 BC at 2 sigma) and $5677 \pm 38{ }^{14} \mathrm{C}$ years BP (38804431 BC at 2 sigma), respectively, determined from a Mactra pura single valve shell at $119 \mathrm{~cm}$ and a Spisula trigonella bivalve shell at $143 \mathrm{~cm}$ (Gehrels et al., 2012).

Pollen samples were prepared for analysis using the method developed by van der Kaars (1991) and discussed in detail in Moss (2013). Sodium pyrophosphate was used to disaggregate the samples, which were then sieved using an $180 \mu \mathrm{m}$ screen to remove the coarse material and an $8 \mu \mathrm{m}$ mesh to split the clays from the silt-sized (including pollen and micro-charcoal) 
TABLE 1 | Chronology of the pollen record (after Gehrels et al., 2012).

\begin{tabular}{|c|c|c|c|c|}
\hline $\begin{array}{l}\text { Depth } \\
\text { (m) }\end{array}$ & $\begin{array}{l}\text { Dating method/ } \\
\text { marker }\end{array}$ & $\begin{array}{l}\text { Age } \\
\text { (AD) }\end{array}$ & $\begin{array}{l}\text { Minimum } \\
\text { age }\end{array}$ & $\begin{array}{c}\text { Maximum } \\
\text { age }\end{array}$ \\
\hline 0.005 & ${ }^{210} \mathrm{~Pb}$ & 2000 & 2011 & 1996 \\
\hline 0.015 & ${ }^{14} \mathrm{C}$ bomb & 1994 & 2001 & 1990 \\
\hline 0.015 & ${ }^{210} \mathrm{~Pb}$ & 1994 & 2001 & 1990 \\
\hline 0.025 & ${ }^{14} \mathrm{C}$ bomb & 1990 & 1994 & 1978 \\
\hline 0.025 & ${ }^{210} \mathrm{~Pb}$ & 1990 & 1994 & 1978 \\
\hline 0.025 & unleaded petrol introduction & 1990 & 1994 & 1978 \\
\hline 0.035 & ${ }^{210} \mathrm{~Pb}$ & 1980 & 1987 & 1968 \\
\hline 0.045 & ${ }^{210} \mathrm{~Pb}$ & 1968 & 1975 & 1963 \\
\hline 0.055 & ${ }^{14} \mathrm{C}$ bomb & 1963 & 1965 & 1961 \\
\hline 0.055 & ${ }^{210} \mathrm{~Pb}$ & 1963 & 1965 & 1961 \\
\hline 0.055 & ${ }^{137} \mathrm{Cs}$ & 1963 & 1965 & 1961 \\
\hline 0.065 & ${ }^{210} \mathrm{~Pb}$ & 1962 & 1963 & 1959 \\
\hline 0.065 & ${ }^{14} \mathrm{C}$ bomb & 1962 & 1963 & 1959 \\
\hline 0.075 & ${ }^{14} \mathrm{C}$ bomb & 1959 & 1960 & 1957 \\
\hline 0.075 & ${ }^{210} \mathrm{~Pb}$ & 1959 & 1960 & 1957 \\
\hline 0.085 & ${ }^{14} \mathrm{C}$ & 1955 & 1956 & 1951 \\
\hline 0.105 & $\begin{array}{l}\text { Start of post WW2 }{ }^{206} \mathrm{~Pb} / 207 \mathrm{~Pb} \\
\text { decline }^{\mathrm{a}}\end{array}$ & 1948 & 1952 & 1944 \\
\hline 0.115 & ${ }^{14} \mathrm{C}$ & 1945 & 1950 & 1940 \\
\hline 0.135 & ${ }^{210} \mathrm{~Pb}$ & 1940 & 1946 & 1932 \\
\hline 0.145 & ${ }^{210} \mathrm{~Pb}$ & 1938 & 1943 & 1928 \\
\hline 0.145 & ${ }^{14} \mathrm{C}$ & 1938 & 1943 & 1928 \\
\hline 0.185 & $\begin{array}{l}\text { Start of large-scale Zn mining, } \\
\text { use of coal for smelting }\end{array}$ & 1926 & 1934 & 1916 \\
\hline 0.195 & ${ }^{14} \mathrm{C}$ & 1922 & 1931 & 1913 \\
\hline 0.275 & ${ }^{14} \mathrm{C}$ & 1896 & 1904 & 1883 \\
\hline 0.285 & Start of ${ }^{206} \mathrm{~Pb} /{ }^{207} \mathrm{~Pb}$ decline ${ }^{\mathrm{a}}$ & 1892 & 1900 & 1874 \\
\hline 0.320 & ${ }^{14} \mathrm{C}$ & 1881 & 1887 & 1861 \\
\hline 0.355 & $\begin{array}{l}\text { Start of catchment disturbance, } \\
\text { Pb enrichment, start of land } \\
\text { clearance }^{a, c, d}\end{array}$ & 1863 & 1874 & 1842 \\
\hline 0.405 & $\begin{array}{l}\text { First appearance of exotic pollen, } \\
\text { micro-charcoal peak }{ }^{\mathrm{d}}\end{array}$ & 1828 & 1842 & 1812 \\
\hline 0.415 & ${ }^{14} \mathrm{C}$ & 1508 & 1620 & 1395 \\
\hline
\end{tabular}

Sources for marker horizon ages: a Van de Velde et al. (2005), 'b Mudd (2009), ' Vallelonga et al. (2002), ${ }^{d}$ Rogers (1991). The minimum and maximum ages indicate the $95 \%$ confidence range and were, for the upper $0.405 \mathrm{~m}$, derived using age modeling software Bacon (Blaauw and Christen, 2011). The methods and raw age data are in Gehrels et al. (2012).

component. The silt fraction then underwent heavy liquid treatment (using sodium polytungstate; specific gravity $\sim 2.0$ ) to separate the organic fraction from the minerogenic component. Acetolysis (using a 9:1 acetic anhydride and concentrated sulphuric acid solution) was then undertaken on the pollen concentrate to remove excess organic material and stain the pollen grains. The samples were then mounted in glycerol for pollen and micro-charcoal was counted at $400 \times$ using a Leica compound light microscope.

Pollen and micro-charcoal concentrations were determined from counts of exotic Lycopodium marker grains that were added as a tablet with a known concentration of Lycopodium clavatum (Stockmarr, 1971; Wang et al., 1999). The pollen sum consisted of a minimum of 300 dryland pollen grains or two completely counted slides, while the micro-charcoal analysis involved counting all black angular fragments $>5$ to $<180 \mu \mathrm{m}$ across three evenly spaced transects at all depths, which meets the minimum requirement of at least 200 items (i.e., sum of exotic marker and micro-charcoal particles) for statistically significant micro-charcoal counts (Finsinger and Tinner, 2005). All of the pollen taxa, family affinities and plant habitat found in the record are shown in Table 1, while the pollen diagram (Figure 3) illustrates the key pollen taxa, micro-charcoal and pollen concentrations and age model. The pollen diagram was produced using TG View (Grimm, 2004), with the pollen sum based on rainforest, sclerophyll arboreal taxa, sclerophyll herbs, exotic taxa, pteridophytes and aquatics. Amaranthaceae (including the former goosefoot family, Chenopodiaceae) were excluded from the pollen sum as they are a local component of the vegetation and are overrepresented in the record. A stratigraphically constrained classification analysis (excluding Amaranthaceae) was undertaken on the raw pollen counts using CONISS (Constrained Incremental Sum of Squares cluster analysis; Grimm, 1987, 2004) to produce pollen zones.

\section{RESULTS}

The 50-cm Little Swanport salt-marsh sediment core provides a continuous record from $1830 \mathrm{AD}$. There is a sedimentation hiatus at $41.5 \mathrm{~cm}$ reflecting a change from intertidal gray mud with rootlets to salt-marsh sediments, with the level below the hiatus dated to ca. 1500 AD (Table 1). For the lower $8.5 \mathrm{~cm}$ of the pollen record we do not have a detailed chronology, but age extrapolation would suggest that the core extends back to ca. $800 \mathrm{AD}$ at $50 \mathrm{~cm}$ depth (Figure 2). The shallow subtidal or low intertidal environment present at the base of the core was in existence for the last ca. 6000 years based on the two shell ages. Gehrels et al. (2012) have provided a detailed discussion of the lithostratigraphy, biostratigraphy and chronostratigraphy for the record, which has been calibrated using the Bayesian agemodeling software Bacon (Blaauw and Christen, 2011). Average sedimentation varies between 2 and $30 \mathrm{~cm} /$ year for the European settlement component of the core.

A total of 52 pollen taxa have been identified from the Little Swanport salt-marsh record, with the dryland component dominated by sclerophyll taxa, primarily Eucalyptus, Melaleuca, Casuarinaceae and Poaceae (Figure 3). There is a minor rainforest component, generally consisting of long traveled (aeolian) pollen grains, such as Nothofagus cunninghamii, Dacrydium franklinii, Podocarpus lawrencei, and Phyllocladus aspleniifolius (Salas, 1983; Kappen and Straka, 1988; D’Costa and Kershaw, 1997). Pommaderris apetala is also present, but that can also be found as an understorey element of wet sclerophyll forest and like most of the rest of the pollen (D'Costa and Kershaw, 1997) and was most likely fluvially transported by the Little Swanport River. Exotic pollen, primarily Asteraceae (Liguliflorae) occurs in the record at $41 \mathrm{~cm}$ and reflects the presence of Europeans in the landscape (around 1830 AD) (von Steiglitz, 1955; Rogers, 1991; Parks and Wildlife Service 


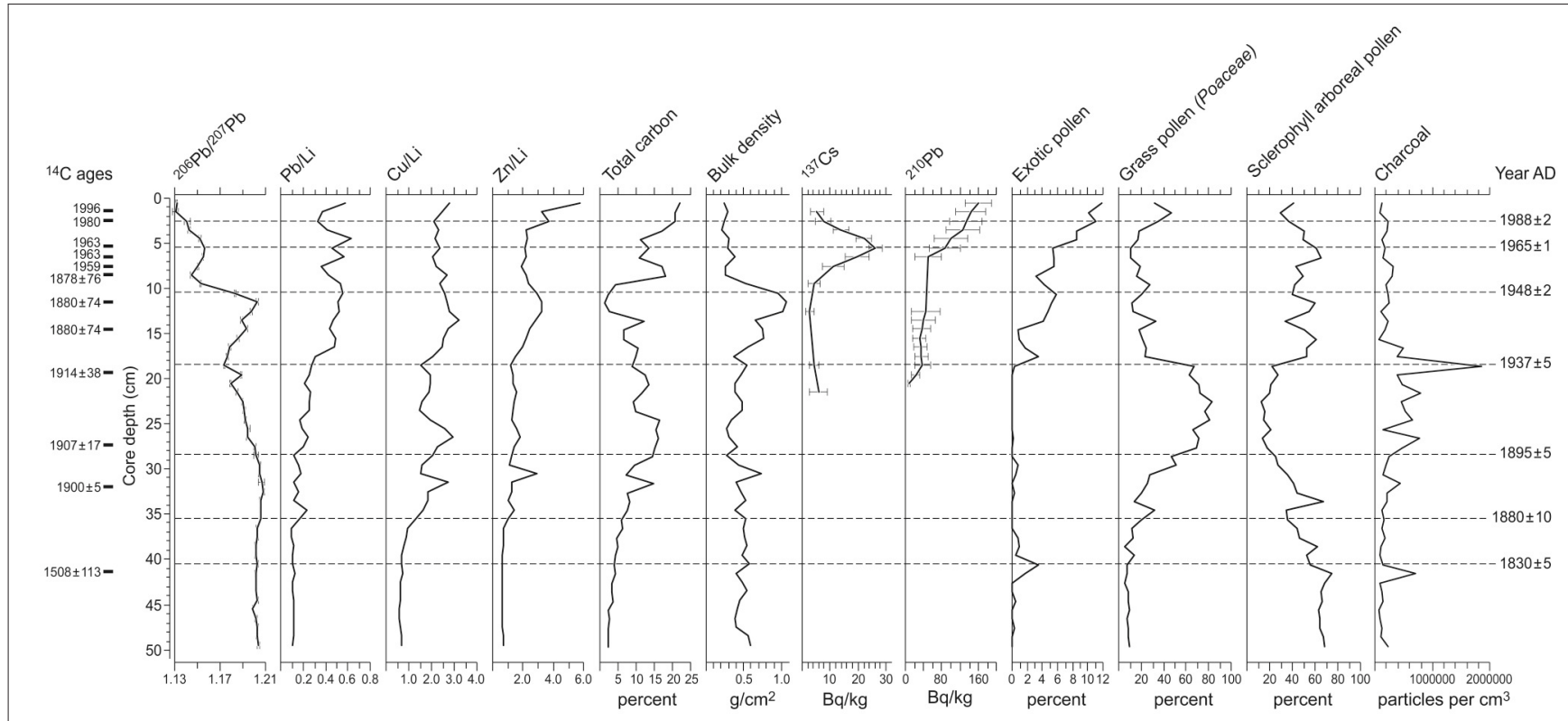

FIGURE 2 | Chronostratigraphy of the core based on ${ }^{14} \mathrm{C}$ AMS ages, ${ }^{210} \mathrm{~Pb}$ ages, ${ }^{137} \mathrm{Cs}$ spike, geochemical (i.e., lead, copper, and zinc reflecting the occurrence of mining/refining within Tasmania and more broadly across South East Australia) and palynological markers. Original figure was presented in the supplementary figures (SA2) of the Gehrels et al. (2012) paper.

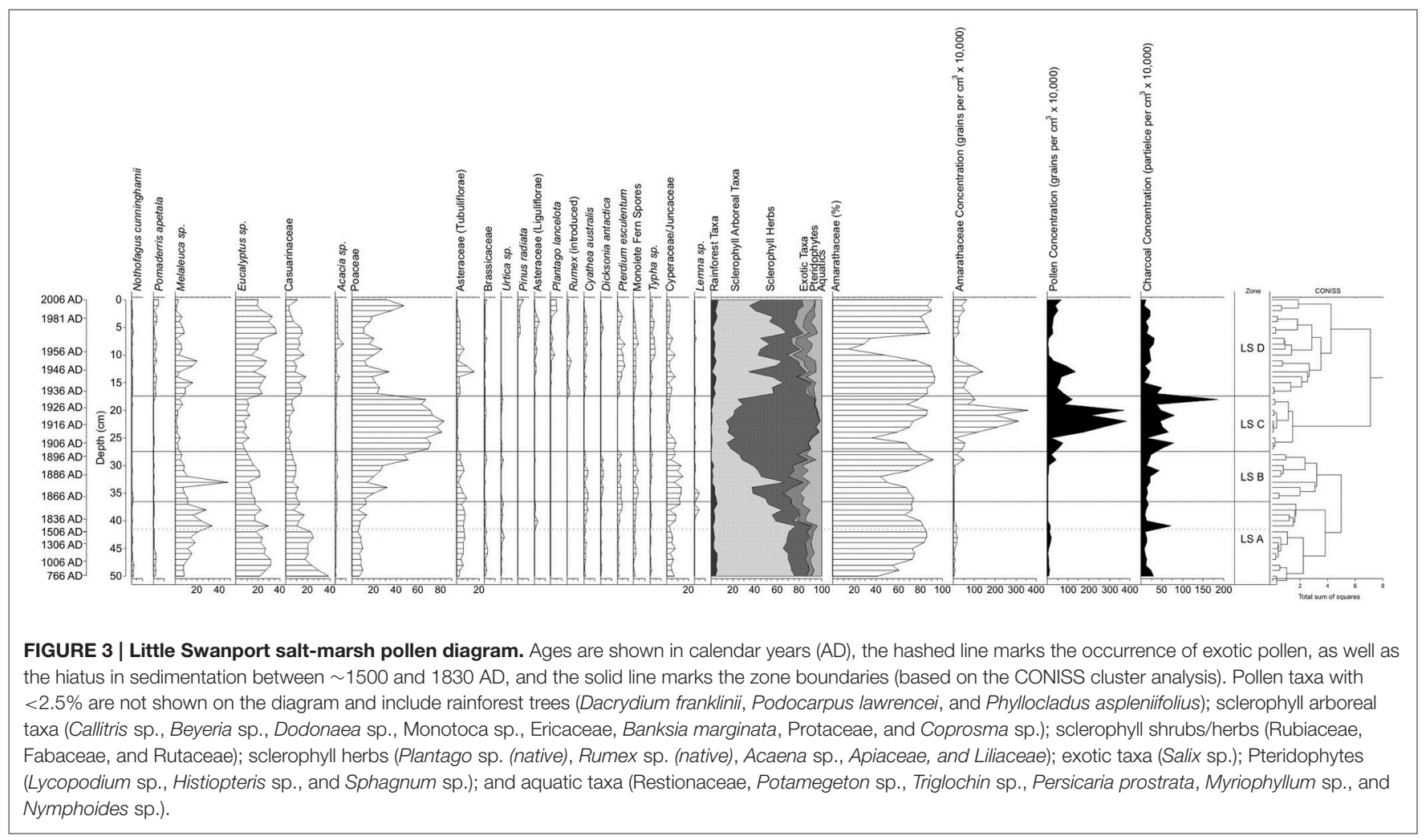

Tasmania, 2016). Pteridophyte values are relatively low, while important aquatic taxa, including Cyperaceae/Juncaceae, which may be a component of the high salt marsh and/or derived from riparian vegetation (Kirkpatrick and Glasby, 1981), as well as other aquatic taxa (most likely from the edge of the upstream Little Swanport River; Kirkpatrick and Harwood, 
1983). Amaranthaceae, which have been excluded from the pollen sum, are the most significant component of the pollen record and reflect the local dominance of the salt-marsh community throughout most of the record (Kirkpatrick and Glasby, 1981). The cluster analysis of the raw pollen data (excluding Amaranthaceae) has identified four pollen zones and these are discussed in detail below.

\section{LS A (50-37 cm; ca. 800 (?) to 1858 AD; Hiatus in Sedimentation between ca. 1500 and $1830 \mathrm{AD}$ )}

This zone is characterized by sclerophyll trees and shrubs (around 46 to $74 \%$ ), with eucalypts, Melaleuca, which increases in abundance at $41 \mathrm{~cm}$, and Casuarinaceae, which declines in abundance at $41 \mathrm{~cm}$, being the most important taxa. Rainforest taxa maintain values of $2-5 \%$, while sclerophyll herbs, primarily Poaceae, and Asteraceae (Tubuliflorae) comprise around 10-20\% of the pollen sum. Brassicaceae maintain higher values below $41 \mathrm{~cm}$ and there is a peak in Urtica at $42 \mathrm{~cm}$. As discussed previously, the exotic pollen marker Asteraceae (Liguliflorae) occurs in the record at $41 \mathrm{~cm}$ at very low values (1-3\%) and is the only exotic taxa present in this zone. Pteridophyte and aquatic taxa maintain low values (around 5 and $10 \%$ respectively), although they both increase (above 10\%) at $41 \mathrm{~cm}$ and there is a peak in the aquatic taxa Lemna at $38 \mathrm{~cm}$. Amaranthaceae percentage values are lower from 50 to $48 \mathrm{~cm}$, which then sharply increase for the rest of the zone, while Amaranthaceae pollen concentrations are low throughout this zone. Pollen concentrations vary from around 26,000 to 148,000 grains per $\mathrm{cm}^{3}$ in this zone, while micro-charcoal values are generally low $\left(\sim 77,000-300,000\right.$ particles per $\left.\mathrm{cm}^{3}\right)$, except for a sharp peak at $41 \mathrm{~cm}\left(714,000\right.$ particles per $\left.\mathrm{cm}^{3}\right)$. The sedimentation rate between 41 and $37 \mathrm{~cm}$ averages ca. $0.14 \mathrm{~cm}$ per year.

\section{LS B (36-28 cm; 1859-1898 AD; Sedimentation Rate $0.2 \mathrm{~cm}$ per Year)}

There is a marked increase (generally above 30\%) in sclerophyll herb abundances, primarily Poaceae and Asteraceae (Tubuliflorae), while sclerophyll arboreal taxa decline (generally below $40 \%$ ), apart from a peak at $33 \mathrm{~cm}$, which is linked to a sharp increase in Melaleuca. Rainforest values decline in this zone from around 5 to $0.2 \%$. Pteridophytes (both tree and ground ferns) and aquatic (primarily Cyperaceae/Juncaceae) taxa increase in this zone and there is a peak in Lemna (at $35-36 \mathrm{~cm}$ ). Salt-marsh representation (\%) is similar to the top of the previous zone, although there is a marked decline in abundances at $33 \mathrm{~cm}$ and Amaranthaceae concentrations maintain similar low values to the previous zone. Pollen concentrations are consistently low in this zone $\left(\sim 15,000-60,000\right.$ grains per $\left.\mathrm{cm}^{3}\right)$, although there is a sharp rise from $29 \mathrm{~cm}$ (above 400,000 grains per $\mathrm{cm}^{3}$ ). A gradual increase in micro-charcoal values (consistently above 120,000 particles per $\mathrm{cm}^{3}$ ) is observed in this zone.

\section{LS C (27-18 cm; 1899-1932 AD; Sedimentation Rate $0.3 \mathrm{~cm}$ per Year)}

This zone observes the highest abundance of sclerophyll herbs, generally above $70 \%$ and consisting almost exclusively of Poaceae, with a marked decline in Asteraceae (Tubuliflorae) representation; the largest pollen concentrations $(>500,000$ grains per $\mathrm{cm}^{3}$ ) in the record, with sharp peaks (almost 4 million grains per $\mathrm{cm}^{3}$ ) at 20 and $22 \mathrm{~cm}$; and highest microcharcoal concentrations, $\sim 150,000-800,000$ particles per $\mathrm{cm}^{3}$ and a peak of 1.9 million particles per $\mathrm{cm}^{3}$ at $18 \mathrm{~cm}$ in the record. There are corresponding sharp declines in rainforest, sclerophyll arboreal taxa, pteridophyte and aquatic values in the record, with the virtual elimination of fern and rainforest representation. Amaranthaceae percentage values generally increase in this zone, although there are two marked declines at 25 and $19 \mathrm{~cm}$. This zone contains the highest salt-marsh pollen concentrations in the record.

\section{LS D (17-0 cm; 1933-2006 AD; Sedimentation Rate $0.2 \mathrm{~cm}$ per Year)}

The sclerophyll herb (primarily Poaceae, which does have increased representation in the top $3 \mathrm{~cm}$ ) values sharply decline in this zone to generally $20-40 \%$, although Asteraceae (Tubuliflorae) abundances do increase and native Plantago has its greatest representation in the record. Sclerophyll arboreal taxa markedly increase (generally $30-50 \%$ ) and Acacia has its highest abundances in the record. Exotic taxa have their highest representation (in terms of abundance and diversity), with introduced Plantago, Rumex, and Asteraceae (Liguliflorae) all increasing, while Pinus radiata becomes more important in the top $5 \mathrm{~cm}$ of the record. Ferns, primarily bracken fern (Pteridium esculentum), also recover to similar abundances observed in zones LS A and B, while aquatic values also rise, mainly linked to increases in Cyperaceae/Juncaceae and Typha (from $10 \mathrm{~cm}$ ). Salt-marsh abundances are generally similar to the previous zone, although there is a sustained and sharp decline in representation from 7 to $10 \mathrm{~cm}$ and this is also reflected in the Amaranthaceae pollen concentration data. Pollen and microcharcoal concentrations sharply decline, although in both cases the values are higher than in zones LS A and B.

\section{DISCUSSION}

The high-resolution pollen and micro-charcoal record derived from the Little Swanport salt marsh in eastern Tasmania provides detailed evidence of the profound impact that European settlement had on the coastal landscape. Overall the palynological data reflect the natural environmental conditions of the Little Swanport River catchment throughout the record with the general dominance of eucalypt-rich sclerophyll forest through most parts of the record, the presence of a Casuarinaceae/Melaleuca-rich coastal community, the trace occurrence of rainforest and the existence of an extensive salt-marsh community, possibly through at least the last 1200 years. Four key phases can be observed with vegetation change associated with European settlement of the region, an early, 
relatively low impact phase from 1830 to $1858 \mathrm{AD}$; a moderate impact period from 1859 to $1898 \mathrm{AD}$; a large scale deforestation phase from 1899 to $1932 \mathrm{AD}$; and a recovery period from 1933 $\mathrm{AD}$ to present. Each phase can be clearly observed in the pollen and micro-charcoal data and suggests that European impacts are linked to a range of social and economic factors that occur from the initial settlement of the Little Swanport region.

There is clear evidence of European settlement of the Little Swanport catchment from $1830 \mathrm{AD}$ through the presence of exotic Asteraceae (Liguliflorae) pollen at $41 \mathrm{~cm}$. This is most likely associated with the development of the Lisdillon salt-works on the northern edge of the Little Swanport Estuary and key impacts appear to be relatively minor (von Steiglitz, 1955; Rogers, 1991; Parks and Wildlife Service Tasmania, 2016). That is, this period is most closely associated with the pre-European period, which is demonstrated by the cluster analysis, rather than the later European phases. There are other subtle indicators of European settlement at this time, including a slight increase in herb and aquatic values from $40 \mathrm{~cm}$ and a micro-charcoal peak at $41 \mathrm{~cm}$ that may represent the initial impacts of land clearance associated with the salt-works. A peak in Lemna at $1848 \mathrm{AD}$ $(38 \mathrm{~cm})$ and 1863 to $1871 \mathrm{AD}(36$ to $35 \mathrm{~cm})$ may also be an indicator of initial European impacts. Lemna or Duckweed can thrive in water with high phosphorous and/or nitrogen content and their presence in the early stages of European settlement may reflect changes in the nutrient status of the catchment linked to the initial land-use patterns, i.e., land clearance around the estuary (Landolt, 1975).

The next phase of settlement (from 1859 to 1898 AD) appears to have a more dramatic impact on the Little Swanport catchment. The overall structure of the catchment is still very similar to the previous period, with the dominance of eucalypt-rich sclerophyll forest and Casuarinaceae/Melaleuca coastal community. However, there is evidence of a general decline in tree pollen representation, which is being replaced by increased values of Poaceae and aquatic taxa, primarily Cyperaceae/Juncaceae. Fern spore abundances, which are often used as a disturbance indicator (Wilmshurst and McGlone, 2005), are also increasing and when taken in combination with the increase in Poaceae/aquatics suggests the development of a more open understorey. One of the key factors that could be driving the development of the opening of the landscape is fire, as the micro-charcoal values from this depth suggest increased burning. This change may be related to increased settlement linked to the development of a road (in 1843) between Little Swanport (and Hobart) to Swansea allowing better access to the region (von Steiglitz, 1955; Smith, 1969). In addition, this period also observed the end of convict transportation to Tasmania (in 1853 $\mathrm{AD}$ ) and a move toward free settlement (Reynolds, 1969), which likely promoted the development of more extensive farms in the region, as prior to this period most major development was associated with the convict labor system (von Steiglitz, 1955).

The third phase, from 1899 to $1932 \mathrm{AD}$, is the most intensive period of European impact on the Little Swanport catchment, with a dramatic expansion in Poaceae that is at the expense of eucalypt forest and woodlands, as well as the coastal forest. This change reflects broad-scale land clearance for extensive agricultural activity that is an important feature of the modern land-use for the region. In particular, extensive areas would have been cleared for sheep production (both fine wool and meat) and cattle grazing (primarily for meat) (LSCPIC, 2010). The time period encompassed observed an increase in wool production in Tasmania, after the 1890s drought and the delay in broad-scale land clearance to the late 1890s may also be related to the presence extensive grasslands/woodlands with grassy understorey in the Oyster Bay region, which would have been developed first rather than the more densely forested Eastern Tiers, which form the upper and middle elevation areas of the catchment (Kirkpatrick, 2007). Another possible consequence of this land clearance phase was a marked increase in sedimentation rates, which is reflected by an increase from 0.2 to $0.3 \mathrm{~cm} /$ year and also by the dramatic increase in pollen concentrations during this period. Similar alterations in sedimentation rates have been observed elsewhere in Tasmania (Thomas and Hope, 1994; Moss et al., 2007), however it could also reflect an increase in salt-marsh accretion in response to accelerated sea-level rise that is observed from 1900 to $1950 \mathrm{AD}$ (Gehrels et al., 2012), or a combination of both factors. Burning, reflected by a marked rise in microcharcoal concentrations, also increases during this period and is associated with the land clearance process (Kirkpatrick, 2007).

The final period, from 1933 to present, observes a recovery in sclerophyll forest and woodland and coastal forest, as well as a decline in sedimentation rates (back to $0.2 \mathrm{~cm} /$ year and a decline in pollen concentrations), which may reflect a decrease in sedimentation rates and/or a slowdown in sea-level rise (Gehrels et al., 2012). The reforestation reflects the establishment of the modern land cover patterns, with extensive cleared areas for grazing across the low and high elevation parts of the catchment and possible reforestation in the mid-elevation areas of the catchment, potentially linked to wood production as this is a major land-use in this region presently (LSCPIC, 2010). In addition, the reforestation occurring during this period may also reflect changes in conservation values, with graziers having a greater appreciation of the environmental benefits (e.g., shade and decreased soil erosion) that trees provide (Kirkpatrick et al., 2007a). Although, there is a clear recovery of forest within the catchment, there is evidence of increased disturbance, with increase representation of exotic taxa, particularly Pinus radiata that represents the establishment of plantation forestry within the catchment after the Second World War (LSCPIC, 2010). Increased representation of exotic taxa also reflects a variety of land uses in combination with grazing, particularly the development of small rural land-holdings in the catchment and diversification of economic activities on the grazing runs (i.e., not just dependant on sheep or cattle production) (Kirkpatrick et al., 2007b; LSCPIC, 2010). In addition, the increase in Typha may be related to the expansion of the exotic species T. latifolia, which can become a problem weed species in Tasmania, although it is difficult to distinguish its pollen from the two native species, T. domingensis and T. orientalis (DPIPWE, 2016). Microcharcoal representation also declines in the LS D zone (although still generally slightly higher than the LS A zone) and suggests a change in fire regimes that could be linked to alterations in land management practices. In particular, there has been a 
decrease in planned burns across Tasmania since the late 1960s (Kirkpatrick, 2007), which may have played a role. It is interesting to note the increase in bracken fern (Pteridium esculentum) that may have contributed to the higher micro-charcoal values that are observed (compared to the pre-European LS A zone). Bracken fern has been linked to changes in fire regimes in New Zealand since human settlement and a similar process may be occurring in the Little Swanport catchment (McGlone et al., 2005). Increased representation of Acacia in the understorey may also be contributing to the alteration in fire regimes during this period.

Some regional comparisons can be made between this site and other locations in Australia. As discussed previously, most records of covering this time period are relatively low-resolution analysis of longer Holocene records. However, there are some higher resolution palynological records that can be compared with this site, including a site from northern Tasmania (Moss et al., 2007) and the midlands region of Tasmania (Romanin et al., 2016) that provides a more detailed picture of European impacts; a high-resolution study from southern South Australia (Bickford and Gell, 2005; Bickford et al., 2008); and records from the Atherton Tableland (Steinberger, 2014). In all cases there is clear evidence of European impacts on the landscape, with the introduction of exotic species, deforestation, changes in species composition and alterations in fire regimes. However, there are key differences between these sites that can be related to the local environmental characteristics, as well as historical context of the settlement period. In the case of Den Plain, northern Tasmania, the effects of European grazing has an almost immediate impact on the landscape when settlement occurred in the $1840 \mathrm{~s} \mathrm{AD}$, with a clear and sustained presence of exotic taxa, a dramatic increase (over 14 times the previous non-European period) in sedimentation rates and a marked deforestation signal with no recovery in forest observed (Moss et al., 2007). A palynological investigation of seven wetlands from the central Tasmanian midlands region observed significant impacts of European settlement, including an increased diversity of exotic herbaceous species, hydrological alterations with open water system transitioning to more ephemeral herb covered wetlands and increased burning associated with the immediate arrival of Europeans, as well as the cessation of traditional Aboriginal fire management (Romanin et al., 2016). The European impacts on the Fleurieu Peninsula, South Australia (Bickford and Gell, 2005; Bickford et al., 2008) were far more subtle during the initial settlement phase, with the key impacts related to changes in fire regimes, with fire sensitive canopy trees (Allocasuarina verticillata) being replaced by fire tolerant eucalypts due to more intense fires occurring as a result of increased fuel loads related to fire suppression. Similar alterations were seen in the swamp flora, with an increase in Acacia in the initial phase, which were then replaced by Leptospermum due to changes in hydrology (related to deforestation in the 1940s and 1950s) impacted the wetlands. Large scale deforestation did not occur in the region until the mid-twentieth century and was associated with intensification in agricultural activity during this time. Steinberger's (2014) palaeoecological and ethnographic analysis of European settlement of the Atherton Tableland reveal a relatively late settlement period (late Nineteenth and early Twentieth century). In this case, the presence of Aboriginal tracks and campgrounds facilitated European settlement of the dense rainforest that characterizes this region, with key towns located in "pockets" of sclerophyll vegetation but taking several decades for the clearance of the dense rainforest to occur for maize and dairy agriculture.

Finally, the Amaranthaceae pollen assemblage from the Little Swanport site suggests that extensive areas of salt marsh have been present for the last 1200 years. For the past few centuries Gehrels et al. (2012) documented changes in foraminiferal abundances which record changes in sea level. There is some feedback between the rate of salt-marsh accretion and sea-level rise. For example, the faster sea-level rise in the early Twentieth century (Gehrels et al., 2012) provided greater accommodation space for the salt marsh compared to the slowdown of sealevel rise in the 1950s, which is reflected in the peak in pollen concentration between 1900 and $1950 \mathrm{AD}$. It is also interesting to note that a similar increase in Amaranthaceae pollen concentration is observed in the late Twentieth and early Twenty First centuries that may represent a response to sea-level rise associated with anthropogenic climate change and also documented in the Little Swanport salt-marsh foraminiferal record, as well as the tide gauges at Spring Bay and Burnie (Gehrels et al., 2012). While sea-level is an important factor in salt-marsh development, other environmental changes can also have dramatic impacts. There are several sharp declines in Amaranthaceae percentages at $1880 \mathrm{AD}(33 \mathrm{~cm}), 1908 \mathrm{AD}$ $(25 \mathrm{~cm}), 1928 \mathrm{AD}(19 \mathrm{~cm})$, and from 1954 to $1965 \mathrm{AD}(7-10 \mathrm{~cm})$. These sharp decreases in salt-marsh pollen may represent a response to human landscape modifications, particularly grazing, and climatic alterations. Prahalad et al. (2012) have documented a decline in salt-marsh extent in south-east Tasmania based on remote sensing data from 1975 to 2009 AD. They suggest that climate change (i.e., increased aridity and sea-level rise) and direct human landscape modifications (i.e., grazing, burning and culvert construction) are responsible for the decline. We do not observe a decline in Amaranthaceae pollen at Little Swanport since the 1990s suggesting that, unlike the salt marshes further to the south, the marsh has been reasonably stable in recent decades. Precipitation and sea-level changes are linked to ENSO, with increased aridity and slow sea-level rise occurring during warm El Niño phases and increased wetness and accelerated sealevel rise prominent during cooler La Niña phases (Goring and Bell, 2001; Feng et al., 2004; Hill et al., 2009). The largest decline in Amaranthaceae pollen between 1954 and 1965 AD occurred during a period with strong El Niño and weaker La Niña years (NOAA, 2016), conditions that would have been conducive to marsh contraction. A study conducted on a salt marsh in northwest Tasmania from aerial photographs from 1952 to 2006 AD found that most of the salt marsh decline was associated with levee construction, grazing, off road vehicles, dumping of rubbish and invasive species (Prahalad, 2014), suggesting in this case that anthropogenic influences were the key factor. Overall, our study and previous work suggest that alterations in salt-marsh extent are related to a complex interaction between sea-level change, climate variability and anthropogenic impacts. Clearly, 
further research is needed to disentangle the relative impacts of these factors on salt-marsh development and to improve our understanding of these important ecosystems in the face of future environmental change.

\section{CONCLUSION}

High-resolution pollen and micro-charcoal analysis of a short $(50 \mathrm{~cm})$ sediment core from a salt marsh in the Little Swanport Estuary, eastern Tasmania provides insight into the impacts of European settlement on the Australian environment over the last +180 years. This period is characterized by deforestation, alterations in species composition and fire regimes, introduction of exotic taxa and a possible increase in sedimentation rates, which is also observed in a host of records across Australia. However, the higher-resolution analysis suggests that more subtle changes occur with the settlement process, with a relatively long transitional phase (1830-1894 AD), followed by a late, rapid deforestation period (1898-1928 AD) and a final reforestation phase (post $1932 \mathrm{AD}$ ) that is markedly different from the pre-European period. When compared to similar records (e.g., Bickford and Gell, 2005; Moss et al., 2007; Bickford et al., 2008; Steinberger, 2014) indicates that both environmental characteristics and the socioeconomic history of the settlement region can influence how a site is impacted, with clear differences in the scale and overall effects of the European occupation period between locations observed. Furthermore, alterations in Amaranthaceae pollen representation reflect a complex interaction between sea-level change, climate variability and human impacts, with further research required to disentangle the

\section{REFERENCES}

Adamson, D. A., and Fox, M. D. (1982). Changes in Australasian Vegetation Since European Settlement. Sydney, NSW: McGraw-Hill.

Benson, J. (1991). The effect of 200 years of European settlement on the vegetation and flora of New South Wales. Cunninghamia 2, 343-370.

Bickford, S. A., and Gell, P. (2005). Holocene vegetation change, Aboriginal wetland use and the impact of European settlement on the Fleurieu Peninsula, South Australia. Holocene 15, 200-215. doi: 10.1191/0959683605hl800rp

Bickford, S. A., Gell, P., and Hancock, G. J. (2008). Wetland and terrestrial vegetation change since European settlement on the Fleurieu Peninsula, South Australia. Holocene 18, 425-436. doi: 10.1177/09596836070 87932

Blaauw, M., and Christen, J. A. (2011). Flexible paleoclimate age-depth models using an autoregressive gamma process. Bayesian Anal. 6, 457-474. doi: $10.1214 / \mathrm{ba} / 1339616472$

BOM (Australian Bureau of Meteorology) (2005). Australia - Climate of Our Continent. Available online at: http://www.bom.gov.au/lam/climate/levelthree/ ausclim/zones.htm (Accessed Augest 6, 2016).

Brown, S. (1991). Aboriginal Archaeological Sites in Eastern Tasmania. Occasional Paper No. 31. Department of Parks, Wildlife and Heritage, Tasmania.

Colhoun, E. A., and Shimeld, P. W. (2012). "Late-Quaternary vegetation history of Tasmania from pollen records," in Peopled Landscapes: Archaeological and Biogeographic Approaches to Landscapes, Terra Australis, Vol. 34 (Canberra: ANU Press), 297-328.

D'Costa, D., and Kershaw, A. P. (1997). An expanded recent pollen database from south-eastern Australia and its potential for refinement of palaeoclimatic estimates. Aust. J. Bot. 45, 583-605. doi: 10.1071/BT96046 relative impacts of these factors on the development of salt-marsh ecosystems.

\section{AUTHOR CONTRIBUTIONS}

PM: Substantial contribution to the conception or design of the work, analysis and interpretation of data; Drafting the work and revising it critically for important intellectual content; Final approval of the version to be published; Agreement to be accountable for all aspects of the work in ensuring that questions related to the accuracy or integrity of the work are appropriately investigated and resolved. WG: Substantial contribution to the conception or design of the work, analysis and interpretation of data; Critically revising the work; Final approval of the published version; Agreement to be accountable for all aspects of the work. SC: Data acquisition and interpretation of data; Critically revising the work; Final approval of the published version; Agreement to be accountable for all aspects of the work.

\section{ACKNOWLEDGMENTS}

For help in the field we thank Nick Callow, Sasha Colecutt, Richard Coleman, Maria Gehrels, Hugh Grenfell, Nick Bowden, Brigid Morrison, and Kelly O' Loughlin. This project was supported by research funds from the School of Geography, Planning and Environmental Management, The University of Queensland. WG was supported by a staff mobility grant from the University of York. We would also like to thank two reviewers whose suggestions greatly improved this paper.

DPIW (2006). Riverine Environmental Analysis for the Little Swanport Catchment. Water Assessment Branch, Water Resources Division. Department of Primary Industry and Water, Technical Report WA 06/03, Tasmania.

Department of Primary Industry, Parks, Water and Environment, Tasmania (DPIPWE) (2016). Invasive Species Cumbungi (Bullrush) Weeds Index. Available online at: http://dpipwe.tas.gov.au/invasive-species/weeds/weeds

Feng, M., Li, Y., and Meyers, G. (2004). Multidecadal variations of Fremantle sea level: Footprint of climate variability in the tropical Pacific. Geophys. Res. Lett. 31, L16302. doi: 10.1029/2004GL0 19947

Finsinger, W., and Tinner, W. (2005). Minimum count sums for charcoal concentration estimates in pollen slides: accuracy and potential errors. Holocene 15, 293-297. doi: 10.1191/0959683605hl808rr

Fletcher, M.-S., Benson, A., Heijnis, H., Gadd, P. S., Cwynar, L. C., and Rees, A. B. (2015). Changes in biomass burning mark the onset an ENSO-influenced climate regime at $42^{\circ} \mathrm{S}$ in southwest Tasmania, Australia. Quat. Sci. Rev. 122, 222-232. doi: 10.1016/j.quascirev.2015.05.002

Fletcher, M.-S., and Moreno, P. I. (2012). Have the Southern Westerlies changed in a zonally symmetric manner over the last 14,000 years? A hemisphere-wide take on a controversial problem. Quat. Int. 253, 32-46. doi: 10.1016/j.quaint. 2011.04.042

Fletcher, M.-S., Wolfe, B. B., Whitlock, C., Pompeani, D. P., Heijnis, H., Haberle, S. G., et al. (2014). The legacy of mid-Holocene fire on a Tasmanian montane landscape. J. Biogeogr. 41, 476-488. doi: 10.1111/jbi.12229

Fogt, R. L., and Bromwich, D. H. (2006). Decadal variability of the ENSO teleconnection to the high-latitude South Pacific governed by coupling with the Southern Annular Mode. J. Clim. 19, 979-997. doi: 10.1175/JCLI 3671.1 
Garreaud, R. D., Vuille, M., Compagnucci, R., and Marengo, J. (2009). Presentday South American climate. Palaeogeogra. Palaeoclimatol. Palaeoecol. 281, 180-195. doi: 10.1016/j.palaeo.2007.10.032

Gehrels, W. R., Callard, S. L., Moss, P. T., Marshall, W. A., Blaauw, M., Hunter, J., et al. (2012). Nineteenth and twentieth century sea-level changes in Tasmania and New Zealand. Earth Planet. Sci. Lett. 315-316, 94-102. doi: 10.1016/j.epsl.2011.08.046

Goring, D., and Bell, R. (2001). Sea level on the move? Water Atmosphere 9, 20-21.

Grimm, E. C. (1987). CONISS: a FORTRAN 77 program for stratigraphically constrained cluster analysis by the method of incremental sum of squares. Comput. Geosci. 13, 13-35. doi: 10.1016/0098-3004(87)90022-7

Grimm, E. C. (2004). TGView Version 2.0.2. Springfield, MA: Illinois State Museum.

Hedge, P., and Kriwoken, L. K. (2000). Evidence for effects of Spartina anglica invasion on benthic macrofauna in Little Swanport estuary, Tasmania. Austral Ecol. 25, 150-159. doi: 10.1046/j.1442-9993.2000. 01016.x

Hendon, H. H., Thompson, D. W., and Wheeler, M. C. (2007). Australian rainfall and surface temperature variations associated with the Southern Hemisphere annular mode. J. Clim. 20, 2452-2467. doi: 10.1016/j.epsl.2011. 08.046

Hill, K. J., Santoso, A., and England, M. H. (2009). Interannual Tasmanian rainfall variability associated with large-scale climate modes. J. Clim. 22, 4383-4397. doi: 10.1175/2009JCLI2769.1

Hobbs, R. J., and Hopkins, A. J. M. (1990). From frontiers to fragments: European impact on Australia's vegetation. Proc. Ecol. Soc. Aust. 16, 93-114.

Kappen, L., and Straka, H. (1988). Pollen and spores transport into the Antarctic. Polar Biol. 8, 173-180. doi: 10.1007/BF00443450

Kershaw, A. P., Bulman, D., and Busby, J. R. (1994). An examination of modern and pre-European settlement pollen samples from southeastern Australia-assessment of their application to quantitative reconstruction of past vegetation and climate. Rev. Palaeobot. Palynol. 82, 83-96. doi: 10.1016/0034-6667(94)90021-3

Kirkpatrick, J. (1999). A Continent Transformed: Human Impact on the Natural Vegetation of Australia, 2nd Edn. Melbourne, VIC: Oxford University Press.

Kirkpatrick, J. B. (2007). "History," in People, Sheep and Nature Conservation: the Tasmanian Experience, eds J. B. Kirkpatrick and K. L. Bridle (Collingwood: CSIRO Publishing), 1-44.

Kirkpatrick, J. B., Bridle, K. L., Edwards, J., and Vercoe, J. (2007a). “Conserving on the run country," in People, Sheep and Nature Conservation: the Tasmanian Experience, eds J. B. Kirkpatrick and K. L. Bridle (Collingwood, ON: CSIRO Publishing), 99-124.

Kirkpatrick, J. B., Bridle, K. L., and Leith, P. (2007b). "Managing the run country for production," in People, Sheep and Nature Conservation: the Tasmanian Experience, eds J. B. Kirkpatrick and K. L. Bridle (Collingwood, ON: CSIRO Publishing), 45-98.

Kirkpatrick, J. B., and Glasby, J. (1981). Saltmarsh in Tasmania: Distribution, Community, Composition and Conservation. Occasional paper no. 8. Department of Geography, University of Tasmania (Hobart, TAS).

Kirkpatrick, J. B., and Harwood, C. E. (1983). Plant communities of Tasmanian wetlands. Aust. J. Bot. 31, 437-451. doi: 10.1071/BT9830437

Landolt, E. (1975). Morphological differentiation and geographical distribution of the Lemna gibba-Lemna minor group. Aquat. Bot. 1, 345-363. doi: 10.1016/ 0304-3770(75)90036-4

Lourandos, H. (1970). Coast and Hinterland: the Archaeological Sites of Eastern Tasmania. Ph.D. dissertation thesis, Australian National University, Canberra, ACT.

Little Swanport Catchment Plan Implementation Committee (LSCPIC) (2010). Little Swanport Catchment Plan 2010-2015. Little Swanport, TAS.

Mackenzie, L., and Moss, P. (in press). A late Quaternary record of vegetation and climate change from Hazards Lagoon, eastern Tasmania. Quat. Int. doi: 10.1016/j.quaint.2014.11.051

McGlone, M. S., Kershaw, A. P., and Markgraf, V. (1992). “El Niño/Southern Oscillation climatic variability in Australasian and south American paleoenvironmental records," in El Niño: Historical and Paleoclimatic Aspects of the Southern Oscillation, eds H. F Diaz and V. Markgraf (Cambridge: Cambridge University Press), 435-462.
McGlone, M. S., Wilmshurst, J. M., and Leach, H. M. (2005). An ecological and historical review of bracken (Pteridium esculentum) in New Zealand, and its cultural significance. N. Z. J. Ecol. 29, 165-184.

Moss, P., Mackenzie, L., Ulm, S., Sloss, C., Rosendahl, D., Petherick, L., et al. (2015). Environmental context for late Holocene human occupation of the South Wellesley Archipelago, Gulf of Carpentaria, northern Australia. Quat. Int. 385, 136-144. doi: 10.1016/j.quaint.2015.02.051

Moss, P. T. (2013). "Palynology and its application to geomorphology", in Treastise in Geomorphology, ed J. F. Shroder (San Diego, CA: Academic Press)

Moss, P. T., Thomas, I., and Macphail, M. (2007). Late Holocene environments of the Mersey Valley, Tasmania. Aust. J. Bot. 55, 74-82. doi: 10.1071/ BT06010

Mudd, G. M. (2009). The Sustainability of Mining in Australia: key Production Trends and their Environmental Implications for the Future. Research Report RR5, Department of Civil Engineering, Monash University and Mineral Policy Institute, April 2009.

NOAA (National Oceanographic and Atmospheric Administration) (2016). El Niño - Southern Oscillation. Available online at: http://www.cpc.noaa.gov/products/precip/CWlink/MJO/enso.shtml\#history (Accessed August 1, 2016).

Parks and Wildlife Service Tasmania (2016). Lisdillon Salt Works. Available online at: http://www.parks.tas.gov.au/index.aspx?base=2686 (Accessed May 10, 2016).

Pitman, A. J., Narisma, G. T., Pielke, R. A. Sr., and Holbrook, N. J. (2004). Impact of land cover change on the climate of southwest Western Australia. J. Geophys. Res. Atmospheres 109, D18109. doi: 10.1029/2003JD004347

Prahalad, V. N. (2014). Human impacts and saltmarsh loss in the Circular Head coast, north-west Tasmania, 1952-2006: implications for management. Pacific Conserv. Biol. 20, 272-285. doi: 10.1071/PC140272

Prahalad, V. N., Kirkpatrick, J. B., and Mount, R. E. (2012). Tasmanian coastal saltmarsh community transitions associated with climate change and relative sea level rise 1975-2009. Aust. J. Bot. 59, 741-748. doi: 10.1071/ BT11206

Rees, A. B., Cwynar, L. C., and Fletcher, M. S. (2015). Southern Westerly Winds submit to the ENSO regime: a multiproxy paleohydrology record from Lake Dobson, Tasmania. Quat. Sci. Rev. 126, 254-263. doi: 10.1016/j.quascirev. 2015.08.022

Reynolds, H. (1969). 'That hated stain': the aftermath of transportation in Tasmania. Hist. Studies 14, 19-31. doi: 10.1080/10314616908595405

Risbey, J., Karoly, D., Reynolds, A., and Braganza, K. (2003). Drought and Climate Change. National Drought Forum. Brisbane, QLD: Department of Primary Industries.

Roberts, N., Meadows, M. E., and Dodson, J. R. (2001). The history of Mediterranean-type environments: climate, culture and landscape. Holocene 11, 631-634. doi: 10.1191/09596830195663

Rogers, B. (1991). Interpretation of an 1830s salt works site on the Little Swanport River, Tasmania. Aust. Hist. Archaeol. 9, 49-55.

Romanin, L. M., Hopf, F., Haberle, S. G., and Bowman, D. M. J. S. (2016). Fire regime and vegetation change in the transition from Aboriginal to European land management in a Tasmanian eucalypt savanna. Aust. J. Bot. 64, 427-440. doi: $10.1071 /$ bt16032

Russell-Smith, J., Yates, C., Edwards, A., Allan, G. E., Cook, G. D., Cooke, P., et al. (2003). Contemporary fire regimes of northern Australia, 1997-2001: change since Aboriginal occupancy, challenges for sustainable management. Int. J. Wildland Fire 12, 283-297. doi: 10.1071/WF03015

Salas, M. R. (1983). Long-distance pollen transport over the southern Tasman Sea: evidence from Macquarie Island. NZ. J. Bot. 21, 285-292. doi: 10.1080/0028 825X.1983.10428559

Shulmeister, J. (1999). Australasian evidence for mid-Holocene climate change implies precessional control of Walker Circulation in the Pacific. Quat. Int. 57, 81-91. doi: 10.1016/S1040-6182(98)00052-4

Smith, R. (1969). Early Tasmanian Bridges. Launceston, TAS: Foot and Playsted.

Steinberger, L. M. M. (2014). Hands in Pockets: Cultural Environments of the Atherton Tablelands of the Past 1,500 Years. Dissertation/Ph.D. thesis, Brisbane, QLD: University of Queensland.

Stockmarr, J. (1971). Tablets with spores used in absolute pollen analysis. Pollen et Spores 13, 615-621. 
Thomas, I., and Hope, G. (1994). An example of Holocene vegetation stability from Camerons Lagoon, a near treeline site on the Central Plateau, Tasmania. Aust. J. Ecol. 19, 150-158. doi: 10.1111/j.1442-9993.1994.tb00478.x

Ulm, S. (2013). 'Complexity' and the Australian continental narrative: themes in the archaeology of Holocene Australia. Quat. Int. 285, 182-192. doi: 10.1016/ j.quaint.2012.03.046

Vallelonga, P., Van de Velde, K., Candelone, J.-P., Morgan, V. I., Boutron, C. F., and Rosman, K. J. R. (2002). The lead pollution history of Law Dome, Antarctica, from isotopic measurements on ice cores: 1500 AD to 1989 AD. Earth Planet. Sci. Lett. 204, 291-306. doi: 10.1016/S0012-821X(02)00983-4

van der Kaars, W. A. (1991). Palynology of eastern Indonesian marine piston cores: A Late Quaternary vegetational and climatic record from Australia. Palaeogeogr. Palaeoclimatol. Palaeoecol. 85, 239-302. doi: 10.1016/00310182(91)90163-L

Van de Velde, K., Vallelonga, P., Candelone, J.-P., Rosman, K. J. R., Gaspari, V., Cozzi, G., et al. (2005). Pb isotope record over one century in snow from Victoria Land, Antarctica. Earth Planet. Sci. Lett. 232, 95-108. doi: 10.1016/ j.epsl.2005.01.007

von Steiglitz, K. R. (1955). Pioneers of the East Coast from 1642: Swansea-Bicheno. Launceston, TAS: Telegraph Printery.
Wang, X., van der Kaars, S., Kershaw, P., Bird, M., and Jansen, F. (1999). A record of fire, vegetation and climate through the last three glacial cycles from Lombok Ridge core G6-4, eastern Indian Ocean, Indonesia. Palaeogeogr. Palaeoclimatol. Palaeoecol. 147, 241-256. doi: 10.1016/S0031-0182(98) 00169-2

Wilmshurst, J. M., and McGlone, M. S. (2005). Corroded pollen and spores as indicators of changing lake sediment sources and catchment disturbance. J. Paleolimnol. 34, 503-517. doi: 10.1007/s10933-0055476-4

Conflict of Interest Statement: The authors declare that the research was conducted in the absence of any commercial or financial relationships that could be construed as a potential conflict of interest.

Copyright (c) 2016 Moss, Gehrels and Callard. This is an open-access article distributed under the terms of the Creative Commons Attribution License (CC BY). The use, distribution or reproduction in other forums is permitted, provided the original author(s) or licensor are credited and that the original publication in this journal is cited, in accordance with accepted academic practice. No use, distribution or reproduction is permitted which does not comply with these terms. 